\title{
Protected or Unprotected Fat Addition for Feedlot Lambs: Feeding Behavior, Carcass Traits, and Meat Quality
}

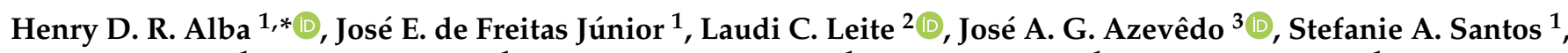 \\ Douglas S. Pina ${ }^{1}$, Luís G. A. Cirne ${ }^{1}$, Carlindo S. Rodrigues ${ }^{1}$, Willian P. Silva ${ }^{1}$, Victor G. O. Lima ${ }^{1}$, \\ Manuela S. L. Tosto ${ }^{1}$ and Gleidson G. P. de Carvalho ${ }^{1, *(1)}$
}

1 Department of Animal Science, Universidade Federal da Bahia, Salvador, 40170110 Bahia, Brazil; jose.esler@ufba.br (J.E.d.F.J.); stefanie_zootecnia@hotmail.com (S.A.S.); douglaspinaufba@gmail.com (D.S.P.); lgabrielcirne@hotmail.com (L.G.A.C.); carlindo.rodrigues@gmail.com (C.S.R.); willianzoo@yahoo.com.br (W.P.S.); victorgolima@hotmail.com (V.G.O.L.); manetosto@hotmail.com (M.S.L.T.)

2 Department of Animal Science, Universidade Federal do Recôncavo da Bahia, Cruz das Almas, 44380000 Bahia, Brazil; laudi.ufrb@gmail.com

3 Department of Animal Science, Universidade Estadual de Santa Cruz, Ilhéus, 45662900 Bahia, Brazil; augustog@uesc.br

* Correspondence: harrydoo@gmail.com (H.D.R.A.); gleidsongiordano@yahoo.com.br (G.G.P.d.C.); Tel.: +55-7199118-7889 (H.D.R.A.); +55-713283-6719 (G.G.P.d.C.)

Citation: Alba, H.D.R.; Freitas Júnior, J.E.d.; Leite, L.C.; Azevêdo, J.A.G.; Santos, S.A.; Pina, D.S.; Cirne, L.G.A.; Rodrigues, C.S.; Silva, W.P.; Lima, V.G.O; ; et al. Protected or Unprotected Fat Addition for Feedlot Lambs: Feeding Behavior, Carcass Traits, and Meat Quality. Animals 2021, 11, 328. https://doi.org/ $10.3390 /$ ani11020328

Received: 28 December 2020

Accepted: 19 January 2021

Published: 28 January 2021

Publisher's Note: MDPI stays neutral with regard to jurisdictional claims in published maps and institutional affiliations.

Copyright: (c) 2021 by the authors Licensee MDPI, Basel, Switzerland. This article is an open access article distributed under the terms and conditions of the Creative Commons Attribution (CC BY) license (https:// creativecommons.org/licenses/by/ $4.0 /)$.
Simple Summary: The use of lipids in ruminant diets aims to increase energy density without affecting the animal's performance; however, its use can be toxic to the ruminal microbiota, which can be avoided with the use of protected fats. Diets with the inclusion of different fat sources (whole soybean grain, corn germ, calcium salt of fatty acids, and soybean oil) were tested to evaluate the effects of unprotected or protected fats on feeding behavior, carcass characteristics, and quality of the meat of feedlot lambs. The use of calcium salts from fatty acids in feedlot lambs' diets improves the quantitative and qualitative characteristics of the carcass and meat.

Abstract: This study aimed to evaluate the effect of the inclusion of protected or unprotected fats in the diet of feedlot lambs on feeding behavior, productive characteristics, carcass traits, and meat quality. Forty male Dorper $\times$ Santa Inês lambs $(22.27 \pm 2.79 \mathrm{~kg})$ were randomly assigned to treatments in a completely randomized design. The experimental treatments consisted of five diets: no added fat (NAF), whole soybeans (WSB), calcium salts of fatty acids (CSFA), soybean oil (SO), and corn germ (CG). The total intake of dry matter (DMI) $(p<0.001)$ and neutral detergent fiber (NDFI) $(p=0.010)$ were higher in the CSFA and NAF diets. Feeding behavior, morphometric measurements, physicochemical characteristics, and centesimal composition of the Longissimus lumborum muscle were similar between treatments $(p>0.05)$. The CSFA diet provided higher production $(p<0.05)$ and better-quality carcasses. The inclusion of fat sources increased the concentration of polyunsaturated fatty acids $(p<0.05)$. The use of calcium salts of fatty acids in feedlot lambs' diets provides better quantitative and qualitative characteristics of the meat and carcass.

Keywords: calcium salt; fatty acid; lipid; ruminant nutrition; sheep

\section{Introduction}

Increasing the energy density in ruminant diets is a practice that correlates with a higher proportion of available metabolizable energy (ME) and the consequent improvement in performance [1]. One method used for this purpose is the addition of lipids to the diet, which provide an energy density 2.25 times greater than carbohydrates [2].

According to the National Research Council (NRC) [3], exceeding the level of 7\% of lipids in ruminant feeding can reduce dry matter intake due to the toxic effect on the ruminal microbiota. That occurs mainly if the fat source has a high content of unsaturated 
fatty acids (UFA) [4]. Although this toxicity mechanism has not been completely elucidated, the principal theory holds that this negative effect is related to the change in membrane fluidity in ruminal microorganisms [5].

Biohydrogenation is the mechanism by which ruminal bacteria protect themselves from UFA. Approximately $70-95 \%$ of linoleic acid and $85-100 \%$ of $\alpha$-linolenic acid are biohydrogenated [6], producing saturated fatty acids (SFA), which will be absorbed in the intestine and directed to the final products, such as meat and milk [7].

The SFAs present in ruminant-derived products are a concern for human health since most of the population considers them responsible for the development of cardiovascular diseases, diabetes, obesity, and cancer [8]. With the use of protected lipids, which will not be biohydrogenated, it is possible to decrease the amount of SFA and to increase the UFA that reaches the small intestine [9].

Among the protected fats, we have those naturally protected, such as oilseeds, where the protein complex present in the cotyledon offers protection to lipids [10]. In chemically protected fats, the binding exerted between salt (main calcium) and fatty acids makes the latter resistant to metabolism of the microbiota of the ruminal environment [11].

Our hypothesis suggests that the addition of protected fat sources in the diet of feedlot lambs will improve feeding behavior and, consequently, the quantitative characteristics of the carcass and meat quality. This study was carried out to evaluate the effect of including fat sources, protected or not, on the feeding behavior, carcass traits, and meat quality of feedlot lambs.

\section{Materials and Methods}

\subsection{Animals, Experimental Design, Management, and Diets}

Forty non-castrated crossbred Dorper $\times$ Santa Inês male lambs (average body weight $(\mathrm{BW}) \pm$ standard deviation: $22.27 \pm 2.79 \mathrm{~kg}$ ) at approximately 4 months of age were randomly assigned to treatments in a completely randomized design. Lambs were housed in individual covered pens $\left(1 \mathrm{~m}^{2}\right)$ with a suspended slatted floor, equipped with drinkers and feeding troughs.

Lambs were kept in a feedlot for 94 days, which were preceded by 15 days of adaptation dedicated to weighing, identifying, vaccinating, and treating the animals for endo- and ectoparasites. During this phase, animals received Tifton-85 hay as roughage (ad libitum) and increasing proportions of the experimental diets for adaptation using corn ground, soybean meal, soybean oil, whole soybean, calcium salts of fatty acids of soybean oil as the fat source (Megalac ${ }^{\circledR}$-E, Vaccinar Ltd.a, Minas Gerais, Brazil), corn germ, urea, and mineral supplement specific for sheep as ingredients of the diets.

The experimental treatments (Table 1 ) consisted of five diets, corresponding to the use of four fat sources: (1) a basal diet without the addition of a fat source (NAF), (2) a diet containing whole soybean (WSB), (3) a diet containing calcium salts of fatty acids of soybean oil (CSFA, Megalac ${ }^{\circledR}$-E, Vaccinar Ltd.a, Minas Gerais, Brazil), (4) a diet containing soybean oil (SO), and (5) a diet containing corn germ (CG).

Diets were formulated as recommended by the NRC [12] to meet the nutritional requirements of lambs with an estimated weight gain of $200 \mathrm{~g} /$ day, with a roughageto-concentrate ratio of 40:60. The feed was supplied twice daily, at 08.00 and $16.00 \mathrm{~h}$. The supplied diets were weighed daily and adjusted to allow refusal of $10 \%$ of the dry matter supplied. 
Table 1. Proportion of ingredients, chemical composition, and fatty acid profile of the experimental diets.

\begin{tabular}{|c|c|c|c|c|c|}
\hline \multirow{2}{*}{ Item } & \multicolumn{5}{|c|}{ Experimental Diets } \\
\hline & NAF & WSB & CSFA & SO & CG \\
\hline \multicolumn{6}{|c|}{ Ingredients (g/kg DM) } \\
\hline Tifton-85 hay & 400.0 & 400.0 & 400.0 & 400.0 & 400.0 \\
\hline Ground corn & 459.0 & 353.0 & 414.0 & 419.0 & 364.0 \\
\hline Soybean meal & 120.0 & 30.0 & 130.0 & 130.0 & 115.0 \\
\hline Soybean oil & - & - & - & 30.0 & - \\
\hline Whole soybean & - & 200.0 & - & - & - \\
\hline $\begin{array}{l}\text { Calcium salt of } \\
\text { fatty acids }\end{array}$ & - & - & 35.0 & - & - \\
\hline Corn germ & - & - & - & - & 100.0 \\
\hline Urea & 6.0 & 2.0 & 6.0 & 6.0 & 6.0 \\
\hline $\begin{array}{c}\text { Mineral } \\
\text { supplement }\end{array}$ & 15.0 & 15.0 & 15.0 & 15.0 & 15.0 \\
\hline \multicolumn{6}{|c|}{ Chemical composition (g/kg DM) } \\
\hline $\begin{array}{c}\text { Dry matter (g/kg } \\
\text { as fed) }\end{array}$ & 900.5 & 903.0 & 903.6 & 903.8 & 904.6 \\
\hline Ash & 52.5 & 54.8 & 57.3 & 52.6 & 52.2 \\
\hline Crude protein & 175.3 & 187.4 & 176.2 & 176.7 & 177.2 \\
\hline Ether extract & 32.6 & 61.6 & 61.2 & 61.1 & 68.5 \\
\hline $\begin{array}{l}\text { Neutral detergent } \\
\text { fiber ap }{ }^{2}\end{array}$ & 349.5 & 358.2 & 345.9 & 346.5 & 365.9 \\
\hline $\begin{array}{l}\text { Acid detergent } \\
\text { fiber ap } \\
3\end{array}$ & 171.9 & 178.1 & 171.4 & 171.5 & 191.2 \\
\hline Lignin & 35.1 & 35.0 & 34.6 & 34.7 & 37.7 \\
\hline $\begin{array}{l}\text { Non-fibrous } \\
\text { carbohydrates }\end{array}$ & 390.0 & 338.0 & 359.4 & 363.1 & 336.2 \\
\hline $\begin{array}{l}\text { Total digestible } \\
\text { nutrients }\end{array}$ & 708.4 & 740.6 & 742.3 & 746.7 & 737.9 \\
\hline $\begin{array}{l}\text { Neutral detergent } \\
\text { insoluble protein }\end{array}$ & 30.7 & 41.0 & 30.3 & 30.4 & 34.1 \\
\hline $\begin{array}{l}\text { Acid detergent } \\
\text { insoluble protein }\end{array}$ & 10.3 & 13.6 & 10.1 & 10.1 & 10.4 \\
\hline \multicolumn{6}{|c|}{ Fatty acid profile (mg/100 g) } \\
\hline Caprylic (C8:0) & 1.0 & 1.0 & 1.0 & 1.3 & 1.3 \\
\hline Capric (C10:0) & 5.1 & 5.1 & 4.7 & 5.3 & 6.8 \\
\hline Lauric (C12:0) & 10.2 & 10.1 & 9.6 & 10.7 & 12.0 \\
\hline Myristic (C14:0) & 61.2 & 60.2 & 56.7 & 61.7 & 113.0 \\
\hline Palmitic (C16:0) & 476.7 & 497.0 & 530.7 & 620.8 & 987.3 \\
\hline Palmitoleic (C16:1) & 13.0 & 13.2 & 14.0 & 14.3 & 20.2 \\
\hline Stearic (C18:0) & 112.4 & 122.2 & 149.4 & 154.9 & 210.1 \\
\hline Oleic (C18:1 n-9) & 786.8 & 804.7 & 967.0 & 916.5 & 2146.2 \\
\hline Linoleic $(C 18: 2 \mathrm{n}-6)$ & 1250.5 & 1356.5 & 1655.3 & 1465.5 & 2949.8 \\
\hline $\begin{array}{c}\alpha \text {-linolenic }(C 18: 3 \\
n-3)\end{array}$ & 57.9 & 77.9 & 112.2 & 78.2 & 85.9 \\
\hline
\end{tabular}

\footnotetext{
${ }^{1}$ Provides per kg of active element: calcium-240.00 g, phosphorus-71.00 g, potassium—28.20 g, sulfur-20.00 g, magnesium-20.00 g, copper $-400.00 \mathrm{mg}$, cobalt $-30.00 \mathrm{mg}$, chromium $-10.00 \mathrm{mg}$, iron $-250.00 \mathrm{mg}$, iodine $-40.00 \mathrm{mg}$, manganese $-1350.00 \mathrm{mg}$, selenium$15.00 \mathrm{mg}$, zinc $-1700.00 \mathrm{mg}$, and fluorine (max.) $-710.00 \mathrm{mg} ;{ }^{2}$ neutral detergent fiber corrected for ash and protein; ${ }^{3}$ acid detergent fiber corrected for ash and protein.
}

\subsection{Sampling and Chemical Analyses}

During the experimental period, samples were collected of the ingredients, diets, and refusals and were stored at $-20^{\circ} \mathrm{C}$. At the end of the experiment, they were dried in a forced-air oven $\left(55^{\circ} \mathrm{C}\right.$ for $72 \mathrm{~h}$ ) and ground in a Wiley mill (model 0.48 , Marconi, Piracicaba, Brazil) to pass through a 1-mm sieve. 
Ingredients, diets, and refusals were analyzed according to the methods of the Association of Official Analytical Chemist (AOAC) [13] for dry matter (DM-method 930.15), crude protein (CP-Kjeldahl procedure; method 976.05), ether extract (EE-method 920.39), and ash (Ash-method 942.05). Neutral detergent fiber corrected to protein and ash (NDFpa), neutral detergent insoluble protein (NDIP), and acid detergent insoluble protein (ADIP) contents were estimated according to the method described by Van Soest et al. [14]. The contents of acid detergent fiber corrected to protein and ash (ADFap) and lignin were calculated as proposed by the AOAC (method 973.18) [15]. Non-fibrous carbohydrates (NFC) content was estimated according to Hall [16], and total digestible nutrients (TDN) were estimated according to the NRC [3] equations.

\subsection{Feeding Behaviour}

The amount of refusal feed was weighed every morning before feeding. Samples of the offered and refusal feed were collected for DM and NDF analysis. Total DM (DMI) and NDF (NDFI) intakes were measured for each animal based on the total feed offered and the refusal amount.

To register the time spent for feeding, rumination, and idling (h/day) visual observation of animals every $5 \mathrm{~min}$ for $24 \mathrm{~h}$ was used, performed by nine experienced observers (they were distributed into three groups which evaluated the feeding behavior for three consecutive hours per group), strategically placed so as not to disturb the animal's comfort, starting at 08.00 . The feeding and rumination efficiencies were obtained by dividing the average daily intake of DM and NDF with the total time spent in $24 \mathrm{~h}$ of feeding and rumination, respectively [17].

In three different periods of the day (10.00-12.00, 14.00-16.00, and 18.00-20.00 $\mathrm{h}$ ), the number of chews and the time spent ruminating the bolus were recorded for each animal. To determine the number of daily cuds, the total rumination time was divided by the average time spent ruminating each cud [18].

\subsection{Slaughter, Carcass Data, and Meat Samples}

After solid fasting for $16.00 \mathrm{~h}$, the animals were slaughtered following humanitarian procedures as required by the Brazilian legislation. First, the animals were numbed by stunning with a pneumatic gun in the atlanto-occipital region, followed by bleeding through the section of the carotid artery and jugular. Subsequently, skinning and evisceration were performed. Immediately, the hot carcass weight $(\mathrm{HCW}), \mathrm{pH}$, and temperature of the hot carcass were measured using a digital $\mathrm{pHmeter}$ equipped with penetrating electrode (HI-99163, Hanna ${ }^{\circledR}$ instruments, São Paulo, Brazil) in the longissimus dorsi muscle between the 4th and 5th lumbar vertebras; following, the carcasses were stored in a cold chamber.

After $24 \mathrm{~h}$ of cooling at $-4{ }^{\circ} \mathrm{C}$, the carcasses were weighed to obtain the cold carcass weight (CCW) and the $\mathrm{pH}$ and temperature were measured. With those data, cooling losses (CL), cold carcass yield (Cold CY), and commercial carcass yield (Commercial CY) were estimated. On the same day, measurements for conformation, finishing, kidney fat, and morphometry were made [19].

The carcasses were sectioned, and the carcasses were divided into six commercial cuts (leg, loin, ribs, lower ribs, neck, and shoulder). In the right loin, a cross-sectional cut was made between the 12th and 13th ribs to expose the longissimus thoracis (LT) muscle to calculate the loin eye area (LEA), and according Cezar e Sousa [19], measurements for marbling and subcutaneous fat thickness in the longissimus lumborum (LL) muscle were made.

\subsection{Physicochemical Meat Analysis}

The meat color was evaluated using a Minolta CR-10 colorimeter (Konica ${ }^{\circledR}$ Minolta, Osaka, Japan) that was previously calibrated with the CIELAB (Commission Internationale de $\mathrm{l}^{\prime}$ Eclairage $\mathrm{L}, \mathrm{a}^{*}, \mathrm{~b}^{*}$ ) system using a blank tile, illuminant D65 and $10^{\circ}$ as the standard observation. The LL muscle was sectioned and exposed to atmospheric air for $30 \mathrm{~min}$ before 
reading the oxygen myoglobin, immediately, the coordinates L* (lightness; L = 0 black, 100 white), $a^{*}$ (redness; ranges from green $(-)$ to red $(+)$ ), and $b^{*}$ (yellowness; ranges from blue $(-)$ to yellow $(+))$ were measured at three different points on the muscle [20].

According to the American Meat Science Association [21], to obtain cooking losses (CL), a LL muscle sample was cooked on a preheated grill (George Foreman Jumbo Grill GBZ6BW, Rio de Janeiro, Brazil) at $170{ }^{\circ} \mathrm{C}$ until the internal temperature of the steak center reached $71^{\circ} \mathrm{C}$, measured using a digital skewer thermometer (Salcasterm $200^{\circledR}$, São Paulo, Brazil). The difference between the initial and final weights of a sample was used to determine CL. After cooling at room temperature, samples of approximately $2 \times 1 \times 1 \mathrm{~cm}$ were cut from the meat to be evaluated for Warner-Bratzler shear force (SF) using a TAXT2 texturometer (Stable Micro Systems Ltd., Vienna Court, UK) at $200 \mathrm{~mm} / \mathrm{min}$ using standard shear blades (1.016 mm thick with a 3.05-mm blade) [22].

The centesimal composition of the LL meat samples was evaluated according to the methods of the AOAC [13] for dry matter (DM-method 930.15), crude protein (CP-Kjeldahl procedure; method 976.05), ether extract (EE-method 920.39), and ash (Ash-method 942.05).

\subsection{Fatty Acid Profile}

To obtain the fatty acid profile, LL meat samples employing the direct method of synthesis of fatty acid methyl esters (FAME) were used according O'Fallon et al. [23].

Fresh meat samples were homogenized by grinding them for 10-15 s in a coffee grinder at room temperature; immediately, the samples were dried by lyophilization for five days. The dried meat samples were made uniform by grinding them for 10-15 $\mathrm{s}$ in a coffee grinder at room temperature. Then, $0.5 \mathrm{~g}$ of a lyophilized sample was placed in a Pyrex culture tube with a screw cap $(16 \times 125 \mathrm{~mm})$ to which $1.0 \mathrm{~mL}$ of the internal standard C19:0 (189-19 Sigma Aldrich, São Paulo, Brazil; $10 \mathrm{mg}$ of C19:0/mL MeOH), $0.7 \mathrm{~mL}$ of $10 \mathrm{~N} \mathrm{KOH}$, and $5.3 \mathrm{~mL}$ of $\mathrm{MeOH}$ were added.

The tube was incubated in a $55^{\circ} \mathrm{C}$ water bath for $1.5 \mathrm{~h}$ with vigorous hand-shaking for 5 s every 20 min to properly permeate, dissolve, and hydrolyze the sample. After cooling below room temperature in a cold tap water bath, $0.58 \mathrm{~mL}$ of $24 \mathrm{~N} \mathrm{H}_{2} \mathrm{SO}_{4}$ was added. The tube was mixed by inversion and, with precipitated $\mathrm{K}_{2} \mathrm{SO}_{4}$ present, was incubated again in a $55{ }^{\circ} \mathrm{C}$ water bath for $1.5 \mathrm{~h}$ with hand-shaking for $5 \mathrm{~s}$ every $20 \mathrm{~min}$. After FAME synthesis, the tube was cooled in a cold tap water bath. Three $\mathrm{ml}$ of hexane was added, and the tube was vortex-mixed for 5 min on a multi-tube vortex. The tube was centrifuged for $5 \mathrm{~min}$ in a tabletop centrifuge, and the hexane layer, containing the FAME, was placed into a gas chromatography (GC) vial. The vial was capped and placed at $-20{ }^{\circ} \mathrm{C}$ until GC analysis.

The fatty acid composition of the FAME sample was determined by capillary GC on a SPTM-2560, $100 \mathrm{~m} \times 25 \mathrm{~mm} \times 0.2 \mu \mathrm{m}$ of film thickness (Supelco), installed on a FOCUS GC gas chromatograph equipped with a flame ionization detector and split injection (Thermo Scientific Inc., São Paulo, Brazil). Hydrogenous $\left(\mathrm{H}_{2}\right)$ was used as a carrier gas $(1 \mathrm{~mL} / \mathrm{min})$, and nitrogen was used as an auxiliary gas. Detector and injector temperatures were set at $250{ }^{\circ} \mathrm{C}$ with a split ratio of $15: 1$. The oven temperature was set at $70{ }^{\circ} \mathrm{C}$ for $4 \mathrm{~min}$, increased by $13{ }^{\circ} \mathrm{C} / \mathrm{min}$ to $175^{\circ} \mathrm{C}$, held for $27 \mathrm{~min}$, increased by $4{ }^{\circ} \mathrm{C} / \mathrm{min}$ to $215^{\circ} \mathrm{C}$, and held for $31 \mathrm{~min}$ [24]. Fatty acids were identified by comparing their retention times with the fatty acid methyl standard described previously.

The atherogenicity (AI) and thrombogenicity (TI) indexes [25] and the hypocholesterolemic-hypercholesterolemic $(\mathrm{h}: \mathrm{H})$ fatty acid ratio [26] were calculated according to the following equations:

$$
\begin{array}{r}
\mathrm{AI}=[(\mathrm{C} 12: 0+(4 \times \mathrm{C} 14: 0)+\mathrm{C} 16: 0)] /\left(\sum \mathrm{AGMI}+\sum \omega 6+\sum \omega 3\right) \\
\mathrm{TI}=(\mathrm{C} 14: 0+\mathrm{C} 16: 0+\mathrm{C} 18: 0) /\left[\left(0.5 \times \sum \mathrm{AGMI}\right)+\left(0.5 \times \sum \omega 6+\left(3 \times \sum \omega 3\right)+\left(\sum \omega 3 / \sum \omega 6\right)\right]\right)
\end{array}
$$

$\mathrm{h}: \mathrm{H}=(\mathrm{C} 18: 1$ cis9 $+\mathrm{C} 18: 2 \omega 6+20: 4 \omega 6+\mathrm{C} 18: 3 \omega 3+\mathrm{C} 20: 5 \omega 3+\mathrm{C} 22: 5 \omega 3+\mathrm{C} 22: 6 \omega 3) /(\mathrm{C} 14: 0+\mathrm{C} 16: 0)$ 
Desirable fatty acids (DFA) were obtained according to Rhee [27]. The activity indexes of the elongase and $\Delta^{9}$-desaturase enzymes were determined using the methodology proposed by Malau-Aduli et al. [28] and Kazala et al. [29], respectively.

\subsection{Statistical Analyses}

Data were subjected to analysis of variance (ANOVA) in a completely randomized design. Mean comparisons were done by Tukey's test, with statistical probability of up to $5 \%$ using the PROC MIXED of SAS 9.4 software, according to the following model:

$$
\hat{Y} i j=\mu+T i+\varepsilon i j
$$

where $\hat{Y}_{\mathrm{ij}}$ is the observed value of the dependent variable, $\mu$ is the overall mean, Ti is the fixed effect of the fat source, and $\varepsilon \mathrm{ij}$ is the experimental random error associated with each presupposition observation NID $(0, \sigma 2)$.

\section{Results}

\subsection{Feeding Behaviour}

There was a higher DMI $(p<0.001)$ and NDFI $(p=0.010)$ in animals fed NAF and CSFA diets (Table 2). The rumination, feeding, idling, and chewing times and the DM and NDF feeding efficiencies of feedlot lambs were not influenced $(p>0.05)$ by the addition of different fat sources in the diet.

Table 2. Feeding behavior of feedlot lambs fed diets containing different fat sources.

\begin{tabular}{|c|c|c|c|c|c|c|c|}
\hline \multirow{2}{*}{ Item } & \multicolumn{5}{|c|}{ Experimental Diets } & \multirow{2}{*}{ SEM } & \multirow{2}{*}{$p$-Value } \\
\hline & NAF & WSB & CSFA & SO & CG & & \\
\hline \multicolumn{8}{|c|}{ Total Intake, kg } \\
\hline Dry matter & $115.9 a$ & $95.3 b$ & $114.0 \mathrm{a}$ & $100.8 \mathrm{~b}$ & $90.6 b$ & 2.455 & $<0.001$ \\
\hline Neutral detergent fiber & $44.7 \mathrm{a}$ & $38.6 b$ & $43.5 \mathrm{a}$ & $38.5 b$ & $36.8 b$ & 0.879 & 0.010 \\
\hline \multicolumn{8}{|c|}{ Time, h/day } \\
\hline Rumination & 8.6 & 8.4 & 7.7 & 8.8 & 8.4 & 0.145 & 0.197 \\
\hline Feeding & 3.2 & 2.9 & 3.1 & 2.6 & 3.4 & 0.106 & 0.081 \\
\hline Idling & 12.2 & 12.7 & 13.2 & 12.6 & 12.2 & 0.196 & 0.476 \\
\hline Chewing & 11.8 & 11.3 & 10.8 & 11.4 & 11.8 & 0.196 & 0.476 \\
\hline \multicolumn{8}{|c|}{ Efficiency, g DM/h } \\
\hline Feeding & 372.5 & 369.2 & 402.3 & 437.9 & 304.5 & 14.851 & 0.057 \\
\hline Rumination & $138.2 \mathrm{ab}$ & $122.1 b$ & $159.9 a$ & $122.1 \mathrm{~b}$ & $115.5 b$ & 3.779 & $<0.001$ \\
\hline \multicolumn{8}{|c|}{ Efficiency, g NDF/h } \\
\hline Feeding & 134.2 & 135.7 & 139.6 & 153.5 & 112.1 & 5.208 & 0.157 \\
\hline Rumination & 49.9ab & $45.0 \mathrm{~b}$ & $55.6 \mathrm{a}$ & $42.7 \mathrm{~b}$ & $42.5 b$ & 1.333 & 0.003 \\
\hline \multicolumn{8}{|c|}{ Cuds } \\
\hline Cuds, $n^{\circ} /$ day & 705.4 & 691.9 & 723.0 & 650.2 & 658.5 & 14.393 & 0.467 \\
\hline Dry matter for cud, $g$ & 1.7 & 1.5 & 1.8 & 1.6 & 1.5 & 0.049 & 0.309 \\
\hline
\end{tabular}

Different lowercase letters indicate differences between columns. Diets: NAF, the basal diet without the addition of a fat source; WSB, whole soybean; CSFA, calcium salt of fatty acids; SO, soybean oil; CG, corn germ.

The animals in this study spent $52.5 \%$ of the day idling $(12.6 \mathrm{~h}), 34.8 \%$ of the day ruminating $(8.4 \mathrm{~h})$, and $12.7 \%$ of the day feeding $(3.0 \mathrm{~h})$. On the other hand, the rumination efficiencies of DM $(p<0.001)$ and NDF $(p=0.003)$ were higher in lambs fed the CSFA diet. No differences were recorded $(p>0.05)$ in the number of cuds per day or the DM for cud (Table 2). 


\subsection{Carcass Traits and Meat Quality}

The inclusion of different fat sources did not influence $(p>0.05)$ the morphometric measurements of the lambs except in the estimation of the carcass compactness index (CCI), where the CSFA diet promoted $(p=0.001)$ a higher CCI in feedlot lambs (Table 3$)$.

Table 3. Morphometric measurements $(\mathrm{cm})$ of the carcass of feedlot lambs fed diets containing different fat sources.

\begin{tabular}{cccccccc}
\hline \multirow{2}{*}{ Item } & \multicolumn{3}{c}{ Experimental Diets } & \multirow{2}{*}{ SEM } & \multirow{2}{*}{$\boldsymbol{p}$-Value } \\
\cline { 2 - 5 } & NAF & WSB & CSFA & SO & CG & & \\
\hline External length & 55.0 & 55.0 & 57.1 & 56.5 & 55.0 & 0.460 & 0.429 \\
Internal length & 53.9 & 53.9 & 54.9 & 54.4 & 52.9 & 0.342 & 0.427 \\
Leg length & 38.7 & 37.9 & 37.7 & 39.2 & 38.1 & 0.339 & 0.626 \\
Leg circumference & 44.9 & 42.2 & 45.9 & 43.6 & 42.3 & 0.503 & 0.066 \\
Thoracic width & 26.0 & 25.2 & 27.1 & 25.9 & 25.3 & 0.295 \\
Thoracic depth & 25.9 & 25.0 & 26.8 & 25.8 & 25.1 & 0.252 & 0.221 \\
Thoracic perimeter & 78.4 & 75.3 & 81.0 & 74.6 & 75.3 & 0.834 & 0.062 \\
Rump width & 21.6 & 20.8 & 23.0 & 21.2 & 21.1 & 0.319 & 0.193 \\
Rump perimeter & 53.7 & 50.8 & 56.3 & 52.3 & 52.6 & 0.765 & 0.207 \\
Carcass compactness index & $0.35 \mathrm{ab}$ & $0.31 \mathrm{~b}$ & $0.38 \mathrm{a}$ & $0.33 \mathrm{ab}$ & $0.30 \mathrm{~b}$ & 0.008 & 0.001 \\
Leg compactness index & 0.56 & 0.55 & 0.61 & 0.54 & 0.56 & 0.011 & 0.222 \\
\hline
\end{tabular}

Different lowercase letters indicate differences between columns. Diets: NAF, the basal diet without the addition of a fat source; WSB, whole soybean; CSFA, calcium salt of fatty acids; SO, soybean oil; CG, corn germ.

The addition of different fat sources in the diet did not influence $(p>0.05)$ the CL, subcutaneous fat thickness, kidney fat, and marbling of feedlot lambs. The CSFA diet provided higher weights $(p<0.05)$ and performance in the lamb carcass compared to lambs fed with other fat sources (Table 4 ).

Table 4. Measures of yield and carcass quality of feedlot lambs fed diets containing different fat sources.

\begin{tabular}{|c|c|c|c|c|c|c|c|}
\hline \multirow{2}{*}{ Item } & \multicolumn{5}{|c|}{ Experimental Diets } & \multirow{2}{*}{ SEM } & \multirow{2}{*}{$p$-Value } \\
\hline & NAF & WSB & CSFA & SO & $\mathrm{CG}$ & & \\
\hline \multicolumn{8}{|c|}{ Carcass traits } \\
\hline Slaughter body weight, kg & $42.8 \mathrm{ab}$ & $39.1 b$ & $45.5 a$ & $42.3 \mathrm{ab}$ & $38.8 b$ & 0.700 & 0.006 \\
\hline Hot carcass weight, kg & $19.2 \mathrm{ab}$ & $16.5 b$ & $21.2 \mathrm{a}$ & $18.1 \mathrm{ab}$ & $16.2 \mathrm{~b}$ & 0.466 & 0.001 \\
\hline Cold carcass weight, kg & $19.1 \mathrm{ab}$ & $16.4 \mathrm{~b}$ & $21.0 \mathrm{a}$ & $18.0 \mathrm{ab}$ & $16.1 \mathrm{~b}$ & 0.461 & 0.001 \\
\hline Cooling losses, $\mathrm{kg}$ & 0.493 & 0.235 & 0.645 & 0.364 & 0.686 & 0.078 & 0.318 \\
\hline Hot carcass yield, \% & $44.6 \mathrm{ab}$ & $42.1 b$ & $46.5 \mathrm{a}$ & $42.8 \mathrm{ab}$ & $41.5 b$ & 0.500 & 0.004 \\
\hline Cold carcass yield, $\%$ & $44.4 \mathrm{ab}$ & $42.0 \mathrm{~b}$ & $46.2 \mathrm{a}$ & $42.7 \mathrm{ab}$ & $41.2 \mathrm{~b}$ & 0.497 & 0.006 \\
\hline \multicolumn{8}{|c|}{ Subjective evaluation } \\
\hline Conformation & $3.4 \mathrm{ab}$ & $3.3 \mathrm{ab}$ & $3.5 \mathrm{a}$ & $3.1 b$ & $3.2 \mathrm{~b}$ & 0.046 & 0.020 \\
\hline Finishing & $3.2 \mathrm{ab}$ & $3.0 \mathrm{ab}$ & $3.4 \mathrm{a}$ & $3.0 \mathrm{ab}$ & $2.9 \mathrm{~b}$ & 0.053 & 0.019 \\
\hline Marbling & 2.7 & 2.5 & 2.8 & 2.1 & 2.0 & 0.109 & 0.086 \\
\hline Kidney Fat & 2.2 & 2.2 & 2.3 & 2.2 & 2.1 & 0.057 & 0.975 \\
\hline \multicolumn{8}{|c|}{ Longissimus lumborum muscle } \\
\hline Loin, kg & $0.96 \mathrm{ab}$ & $0.84 \mathrm{~b}$ & $1.14 \mathrm{a}$ & $0.97 \mathrm{ab}$ & $0.80 \mathrm{~b}$ & 0.030 & 0.001 \\
\hline Loin eye area, $\mathrm{cm}^{2}$ & $12.3 \mathrm{ab}$ & $11.1 \mathrm{~b}$ & $14.0 \mathrm{a}$ & $12.0 \mathrm{ab}$ & $10.0 \mathrm{~b}$ & 0.368 & 0.004 \\
\hline Subc. fat thickness, $\mathrm{mm}$ & 2.6 & 2.1 & 2.6 & 2.9 & 2.8 & 0.190 & 0.708 \\
\hline
\end{tabular}

Different lowercase letters indicate differences between columns. Diets: NAF, the basal diet without the addition of a fat source; WSB, whole soybean; CSFA, calcium salt of fatty acids; SO, soybean oil; CG, corn germ.

The physicochemical characteristics and centesimal composition of the LL muscle were not influenced $(p>0.05)$ by the inclusion of different fat sources in the diet of feedlot lambs (Table 5). 
Table 5. Physicochemical characteristics and centesimal composition of the longissimus lumborum (LL) muscle of lambs fed diets containing different fat sources.

\begin{tabular}{|c|c|c|c|c|c|c|c|}
\hline \multirow{2}{*}{ Item } & \multicolumn{5}{|c|}{ Experimental Diets } & \multirow{2}{*}{ SEM } & \multirow{2}{*}{$p$-Value } \\
\hline & NAF & WSB & CSFA & SO & CG & & \\
\hline \multicolumn{8}{|c|}{ Physicochemical characteristics } \\
\hline $\mathrm{pH} 45 \mathrm{~min}$ & 7.1 & 7.0 & 7.1 & 7.1 & 7.1 & 0.040 & 0.902 \\
\hline $\mathrm{pH} 24 \mathrm{~h}$ & 5.9 & 5.6 & 5.9 & 5.7 & 5.7 & 0.035 & 0.149 \\
\hline $\mathrm{T}^{\circ} 45 \mathrm{~min},{ }^{\circ} \mathrm{C}$ & 31.2 & 31.9 & 30.9 & 30.9 & 31.2 & 0.294 & 0.813 \\
\hline $\mathrm{T}^{\circ} 24 \mathrm{~h},{ }^{\circ} \mathrm{C}$ & 9.6 & 9.2 & 9.4 & 9.6 & 9.5 & 0.103 & 0.679 \\
\hline Cooking losses, $\%$ & 29.9 & 25.5 & 39.1 & 36.4 & 25.1 & 2.103 & 0.106 \\
\hline Shear force, $\mathrm{kgf} / \mathrm{cm}^{2}$ & 2.7 & 2.8 & 2.9 & 2.7 & 2.7 & 0.069 & 0.933 \\
\hline Lightness, L * & 40.2 & 40.8 & 38.6 & 40.4 & 41.6 & 0.489 & 0.401 \\
\hline Redness, $a *$ & 21.7 & 22.0 & 22.5 & 22.7 & 22.5 & 0.201 & 0.572 \\
\hline Yellowness, $b$ * & 6.9 & 7.6 & 7.3 & 7.8 & 7.8 & 0.245 & 0.757 \\
\hline \multicolumn{8}{|c|}{ Centesimal composition of LL muscle (g/kg) } \\
\hline Dry matter & 273.6 & 277.8 & 269.6 & 268.7 & 266.4 & 0.176 & 0.253 \\
\hline Moisture & 726.4 & 722.2 & 730.4 & 731.3 & 733.6 & 0.176 & 0.253 \\
\hline Ash & 8.6 & 9.0 & 8.7 & 9.2 & 9.3 & 0.017 & 0.679 \\
\hline Ether extract & 37.3 & 39.6 & 36.5 & 30.2 & 31.8 & 0.157 & 0.277 \\
\hline Crude protein & 213.7 & 214.9 & 217.2 & 221.3 & 229.5 & 0.207 & 0.096 \\
\hline
\end{tabular}

Different lowercase letters indicate differences between columns. Diets: NAF, the basal diet without the addition of a fat source; WSB, whole soybean; CSFA, calcium salt of fatty acids; SO, soybean oil; CG, corn germ.

\subsection{Fatty Acids}

The SFA C12:0, C14:0, C15:0, and C16:0 and UFA C16:1 $c 9$ and C18:2 t10c12 in the LL muscle of lambs fed different fat sources were similar $(p>0.05)$. However, stearic acid (C18:0) was $49.6 \%$ higher in the CG diet compared to that in the CSFA diet, which in turn had a lower content of this fatty acid. The highest concentration of branched-chain fatty acid (BCFA) C17:0 was in the NAF diet, and that of C18:0 was in the CSFA diet (Table 6).

The LL muscle of the lambs fed the CSFA, SO, and CG diets showed the highest concentrations of CLA (C18:2 c9t11) and the lowest concentrations of oleic acid (C18:1 c9). The content of vaccenic acid (C18:1 t11) was higher $(p<0.001)$ in lambs fed the CSFA diet, $324 \%$ higher than the concentration observed in the NAF diet. The production of FA derived from biohydrogenation was higher for the CSFA diet. The polyunsaturated fatty acids C18:2 c9c12, C18:3 n-3, C20:4 n-6, C20:5 n-3, C22:5 n-3, and C22:6 n-3 were always higher $(p<0.05)$ in the LL muscle from lambs fed the WSB diet (Table 6). 
Table 6. Fatty acid composition (mg/100 g of meat) of the LL muscle of lambs fed diets containing different fat sources.

\begin{tabular}{|c|c|c|c|c|c|c|c|}
\hline \multirow{2}{*}{ Fatty Acid } & \multicolumn{5}{|c|}{ Experimental Diets } & \multirow{2}{*}{ SEM } & \multirow{2}{*}{$p$-Value } \\
\hline & NAF & WSB & CSFA & SO & CG & & \\
\hline \multicolumn{8}{|c|}{ Saturated fatty acids } \\
\hline Lauric (C12:0) & 3.0 & 3.14 & 2.6 & 2.2 & 2.7 & 0.147 & 0.271 \\
\hline Myristic (C14:0) & 76.5 & 73.95 & 72.6 & 59.7 & 65.5 & 3.141 & 0.444 \\
\hline Pentadecanoic (C15:0) & 10.7 & 12.06 & 8.5 & 9.0 & 10.6 & 0.562 & 0.241 \\
\hline Palmitic (C16:0) & 911.5 & 863.1 & 779.4 & 698.7 & 767.9 & 31.256 & 0.242 \\
\hline Stearic (C18:0) & $581.1 \mathrm{~b}$ & $735.5 \mathrm{ab}$ & $538.6 c$ & $609.4 b c$ & $805.5 a$ & 32.856 & 0.028 \\
\hline \multicolumn{8}{|c|}{ Branched-chain fatty acids } \\
\hline C14:0 iso & 1.2 & 1.59 & 1.0 & 1.1 & 1.5 & 0.098 & 0.232 \\
\hline $\mathrm{C} 15: 0$ iso & 4.9 & 5.60 & 3.4 & 4.1 & 4.6 & 0.304 & 0.199 \\
\hline C15:0 anteiso & 5.0 & 6.4 & 3.8 & 4.9 & 5.8 & 0.353 & 0.206 \\
\hline $\mathrm{C} 16: 0$ iso & 6.4 & 6.8 & 4.4 & 5.9 & 6.3 & 0.400 & 0.400 \\
\hline $\mathrm{C} 17: 0$ iso & $1.4 \mathrm{a}$ & $0.8 b$ & $0.8 \mathrm{~b}$ & $0.6 \mathrm{~b}$ & $0.5 b$ & 0.086 & 0.008 \\
\hline $\mathrm{C} 18: 0$ iso & $1.5 \mathrm{c}$ & $1.3 \mathrm{c}$ & $3.2 \mathrm{a}$ & $2.2 \mathrm{~b}$ & $1.8 \mathrm{bc}$ & 0.160 & $<0.001$ \\
\hline \multicolumn{8}{|c|}{ Monounsaturated fatty acids } \\
\hline Palmitoleic (C16:1) & 55.7 & 55.2 & 51.8 & 44.9 & 39.7 & 2.247 & 0.089 \\
\hline Oleic (C18:1 n-9) & $1741.4 \mathrm{a}$ & $1483.8 \mathrm{ab}$ & $1215.0 \mathrm{~b}$ & $1304.8 b$ & $1360.8 b$ & 58.839 & 0.041 \\
\hline Vaccenic (C18:1 t11) & $33.8 \mathrm{~d}$ & $62.8 \mathrm{~cd}$ & $143.1 \mathrm{a}$ & $101.9 \mathrm{~b}$ & $88.4 \mathrm{bc}$ & 8.826 & $<0.001$ \\
\hline \multicolumn{8}{|c|}{ Polyunsaturated fatty acids } \\
\hline Linoleic (C18:2 c9c12) & $103.2 \mathrm{c}$ & $199.4 a$ & $158.6 \mathrm{~b}$ & $159.8 b$ & $170.3 a$ & 8.609 & 0.001 \\
\hline CLA $^{1}$ & $7.5 b$ & $9.7 \mathrm{~b}$ & $22.5 a$ & $18.3 \mathrm{a}$ & $19.0 \mathrm{a}$ & 10.439 & 0.002 \\
\hline CLA isomer (C18:2 t10c12) & 0.9 & 0.7 & 1.2 & 0.9 & 0.7 & 0.075 & 0.149 \\
\hline$\alpha$-linolenic (C18:3n-3) & $6.9 c$ & $12.1 \mathrm{a}$ & $7.9 \mathrm{bc}$ & $9.2 \mathrm{~b}$ & $5.2 \mathrm{~d}$ & 0.543 & $<0.001$ \\
\hline Arachidonic (C20:4 n-6) & $36.8 b$ & $42.5 \mathrm{a}$ & $29.7 \mathrm{c}$ & $42.8 \mathrm{a}$ & $42.4 \mathrm{a}$ & 1.280 & $<0.001$ \\
\hline $\begin{array}{c}\text { Eicosapentaenoic (EPA; C20:5 } \\
n-3)\end{array}$ & $4.3 a$ & $4.9 \mathrm{a}$ & $3.1 b$ & $4.6 \mathrm{a}$ & $3.0 \mathrm{~b}$ & 0.198 & $<0.001$ \\
\hline $\begin{array}{l}\text { Docosapentaenoic (DPA; } \\
\text { C22:5n-3) }\end{array}$ & $6.3 \mathrm{bc}$ & $8.3 a$ & $5.3 c$ & 7.1ab & $5.7 \mathrm{bc}$ & 0.307 & 0.004 \\
\hline $\begin{array}{c}\text { Docosahexaenoic (DHA; } \\
\text { C22:6 n-3) }\end{array}$ & $1.2 \mathrm{ab}$ & $1.9 \mathrm{a}$ & $0.8 \mathrm{bc}$ & $1.4 \mathrm{ab}$ & $1.1 \mathrm{bc}$ & 0.113 & 0.037 \\
\hline
\end{tabular}

Different lowercase letters indicate differences between columns. Diets: NAF, the vasal diet without the addition of a fat source; WSB, whole soybean; CSFA, calcium salt of fatty acids; SO, soybean oil; CG, corn germ; ${ }^{1}$ CLA, conjugated linoleic acid (coeluted peak with $\mathrm{C} 18: 2 \mathrm{t} 7 \mathrm{c} 9$ and $\mathrm{C} 18: 2 \mathrm{c} 9 \mathrm{t} 11)$.

While the WSB diet promoted the highest concentration $(p<0.05)$ of total saturated fatty acids ( $\Sigma S F A)$, the CSFA and SO diets showed the lowest $(p=0.025)$ (Table 7$)$. There were no changes $(p>0.05)$ in the concentrations of total monounsaturated fatty acids ( MUFA). However, the addition of different sources of fats in the feeding of feedlot lambs promoted a higher concentration $(p<0.001)$ of total polyunsaturated fatty acids ( $\Sigma$ PUFA) in meat compared to the NAF diet.

The PUFA:SFA ratio was higher $(p<0.001)$ in the CSFA and SO diets. The inclusion of whole soybeans, soybean oil, and corn germ promoted an increase $(p<0.05)$ in the concentration of fatty acids in the omega 6 series ( $\Sigma$ PUFA n-6). However, the concen-

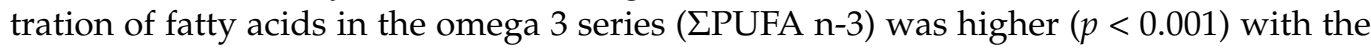
addition of whole soybeans in the diet. The highest n-6:n-3 ratio was observed with the CG diet, and the lowest was observed with the WSB $(p<0.001)$. The WSB diet promoted $(p<0.01)$ the highest atherogenic (AI) and thrombogenic (TI) indexes. The hypocholesterolemic and hypercholesterolemic ratio $(\mathrm{h}: \mathrm{H})$ increased $(p=0.006)$ with the NAF, SO, and CG diets (Table 7).

A higher activity $(p<0.05)$ of the enzyme $\Delta 9$ C18 desaturase was found in the meat of lambs fed the NAF diet. On the other hand, the highest activity $(p<0.001)$ of elongase was estimated for the SO and GC diets (Table 7). 
Table 7. Fatty acid classes (mg/100 g of meat), ratios, indexes, and enzyme activity in the LL muscle of lambs fed diets containing different fat sources.

\begin{tabular}{|c|c|c|c|c|c|c|c|}
\hline \multirow{2}{*}{ Item $^{1}$} & \multicolumn{5}{|c|}{ Experimental Diets } & \multirow{2}{*}{ SEM } & \multirow{2}{*}{$p$-Value } \\
\hline & NAF & WSB & CSFA & SO & CG & & \\
\hline$\Sigma$ SFA & $1635.1 \mathrm{ab}$ & $1962.1 \mathrm{a}$ & $1437.4 b$ & $1417.8 \mathrm{~b}$ & $1695.9 \mathrm{ab}$ & 58.864 & 0.025 \\
\hline$\Sigma$ MUFA & 1877.2 & 1754.7 & 1448.3 & 1478.7 & 1513.1 & 57.893 & 0.065 \\
\hline$\Sigma$ PUFA & $178.8 \mathrm{~b}$ & $270.0 \mathrm{a}$ & $247.8 \mathrm{a}$ & $254.4 \mathrm{a}$ & $250.5 a$ & 7.882 & $<0.001$ \\
\hline PUFA:SFA & $0.11 c$ & $0.14 \mathrm{~b}$ & $0.17 \mathrm{a}$ & $0.18 \mathrm{a}$ & $0.15 b$ & 0.006 & $<0.001$ \\
\hline$\Sigma$ PUFA n-6 & $39.1 b$ & $45.4 \mathrm{a}$ & $32.0 \mathrm{c}$ & $46.0 \mathrm{a}$ & $45.2 \mathrm{a}$ & 1.355 & $<0.001$ \\
\hline$\Sigma$ PUFA n-3 & $18.3 b c$ & $25.4 a$ & $16.4 \mathrm{c}$ & $21.1 b$ & $15.6 \mathrm{c}$ & 0.847 & $<0.001$ \\
\hline n-6:n-3 & $2.07 \mathrm{~b}$ & $1.61 \mathrm{c}$ & $1.98 \mathrm{~b}$ & $1.96 \mathrm{bc}$ & $3.33 a$ & 0.130 & $<0.001$ \\
\hline AI & $0.60 \mathrm{~b}$ & $0.67 \mathrm{a}$ & $0.62 \mathrm{ab}$ & $0.53 c$ & $0.57 \mathrm{bc}$ & 0.013 & 0.004 \\
\hline $\mathrm{TI}$ & $1.7 \mathrm{~b}$ & $2.0 \mathrm{a}$ & $1.8 \mathrm{~b}$ & $1.7 \mathrm{~b}$ & $2.0 \mathrm{a}$ & 0.040 & $<0.001$ \\
\hline h:H & $1.8 \mathrm{a}$ & $1.6 \mathrm{~b}$ & $1.5 b$ & $1.8 \mathrm{a}$ & $1.8 \mathrm{a}$ & 0.036 & 0.006 \\
\hline$\Delta^{9} \mathrm{C} 18$ & $74.4 \mathrm{a}$ & $65.6 \mathrm{~cd}$ & $69.3 b$ & $68.1 b c$ & $63.6 \mathrm{~d}$ & 0.892 & $<0.001$ \\
\hline Elongase & $70.5 b$ & $70.6 b$ & $67.9 c$ & $72.7 \mathrm{a}$ & $72.8 \mathrm{a}$ & 0.465 & $<0.001$ \\
\hline DFA & 2631.6 & 2869.9 & 2234.8 & 2342.6 & 2646.6 & 81.703 & 0.097 \\
\hline
\end{tabular}

Different lowercase letters indicate differences between columns. Diets: NAF, the basal diet without the addition of a fat source; WSB, whole soybean; CSFA, calcium salt of fatty acids; SO, soybean oil; CG, corn germ. ${ }^{1}$ AI, atherogenicity index; TI, thrombogenicity index; $\mathrm{h}: \mathrm{H}$, hypocholesterolemic-hypercholesterolemic ratio; $\Delta^{9} \mathrm{C} 16$, delta-9 hexadecanoic-CoA desaturase; $\Delta^{9} \mathrm{C} 18$, delta-9 octadecanoicCoA desaturase; DFA, desirable fatty acids.

\section{Discussion}

\subsection{Feeding Behaviour}

The higher total intake of DM and NDF from the NAF and CSFA diets suggests that chemically protected fats avoid adverse effects on the ruminal microbiota, which did not occur in the WSB, SO, and CG diets. In these latter diets, EE may have contributed to reducing intake [30], promoting two apparent effects: selectivity and/or toxicity. However, the intake changes did not compromise the time spent on the main activities of feeding behavior (ruminating, feeding, idling, and chewing).

According to Owens and Basalam [31], feeding time can vary from 1 to $12 \mathrm{~h} /$ day. The average feeding time of $3 \mathrm{~h} /$ day in the present experiment is probably related to the type of diet (total mixed ration, $60 \%$ concentrate), thus avoiding the animals spending excessive time in the trough with the selection of specific ingredients.

In the current study, the concentrations of fibrous carbohydrates in the diets (NDF and ADF) were similar, showing an average rumination time of $8.4 \mathrm{~h} /$ day. Costa et al. [32] indicated that, regardless of the concentration of nondigestible neutral detergent fiber in the diet, lambs with high intake rates have shorter rumination times. Numerically, the rumination time was short in lambs fed the CSFA diet, which may have promoted higher DM and NDF rumination efficiencies.

\subsection{Carcass Traits and Meat Quality}

The absence of a significant effect in the morphometric measurements of the carcass (except for CCI) can be explained by the isometric development and parallel evolution of the carcass growth, which resulted in an anatomical harmony [33]. On the other hand, the low standard error of the mean suggest that the effect of environmental factors was not significant [34].

The use of lipids in diets for ruminants increases the content of ME as well as protein use efficiency [35]. The addition of fatty acid salts promotes higher DM intake [36]. Therefore, the higher carcass yields observed in lambs fed the CSFA diet can be explained due to the better use of DM for growth development.

Medium and long-chain fatty acids generate ATP more efficiently than volatile fatty acids generated in the rumen [1]. In this way, this energy contributed to muscle forma- 
tion and growth in the animals of the present study. Bhatt et al. [37] observed a higher performance of lambs fed diets with high levels of PUFAs.

The CSFA diet provided higher productive performance. This result is confirmed by the compactness carcass index, which indicates a higher deposition of muscle tissue per unit of length. The productive performance is related to the process of synthesis, degradation, and deposition of body proteins, which needs higher amounts of energy that can be supplied by diet [38].

Nutritional management is one of the main factors that affect the quantity and quality characteristics of the carcass and meat [39]. In this study, no influence of the inclusion of fat sources in the diets was observed on the physicochemical characteristics of the carcass or centesimal composition of the LL muscle, which is in agreement with several studies in this area [40-42].

The $\mathrm{pH}$ of sheep meat is close to neutral in live animals and decreases to 5.4-5.8 after $24 \mathrm{~h}$ of slaughter under normal conditions [43-45]. In the current study, the mean $\mathrm{pH}$ value of the meat was 5.8. The result obtained suggests that the animals did not suffer stress before slaughter or increased glycolysis after slaughter [46]. The importance of evaluating the meat $\mathrm{pH}$ lies in its importance in influencing other parameters such as color, tenderness, and microbiological stability, among others $[44,46]$.

The average CL value of $31 \%$ was lower than the values (35.11-38.4\%) reported in lamb meat $[45,47,48]$. The CL is correlated with the amount of intra-, inter-, and extramuscular lipids. Therefore, the similarity between the carcasses can be supported by the lack of differences in their lipid content (subcutaneous and marbling fat). It is important to highlight that, the lower the CL values, the better the benefits concerning the tenderness of the meat obtained [49].

The SF is related to factors such as age [50], collagen solubility [51], lipid accumulation [49], and weight of the animals. Values between 2.35 and $4.08 \mathrm{kgf} / \mathrm{cm}^{2}$ can be observed in sheep meat [52], considering ideal values at less than $3.4 \mathrm{kgf} / \mathrm{cm}^{2}$ [53]. Therefore, the FS of $2.8 \mathrm{kgf} / \mathrm{cm}^{2}$ observed in the current study is considered soft.

Although the EE content of diets with some fat sources (6.31\%) was almost double that of the NAF diet (3.26\%), the proximal composition of the LL muscle was similar among lambs. Renal, subcutaneous, and marbling fat values in lamb carcasses indicate that dietary lipids were primarily used as an energy source for production and were stored in smaller amounts [54].

\subsection{Fatty Acid Profile}

Odd- and branched-chain fatty acids (OBCFA) are formed by ruminal bacteria from the elongation of propionate, valerate, valine, leucine, and isoleucine [55]. Animals fed a higher amount of NFC have a higher proportion of OBCFA precursors [56]. Dietary fat inclusion (WSB, CSFA, SO, and CG) were related to decreased levels of NFC in the diets, which explains the reason for the concentrations of FA C17:0 iso being higher with the NAF diet.

The C18:0 iso concentration was higher with the CSFA diet, and this can be explained by the fact that calcium salts do not affect the ruminal cellulolytic bacterial population [9]. Related to this, even- and branched-chain fatty acids, mainly iso, are correlated with a higher population of cellulolytic bacteria in the rumen ( $R$. albus, B. fibrisolvens, and R. flavefaciens) [57].

The higher content of C18:2 c9c12 in the LL muscle was observed in lambs fed the WSB and CG diets. This result suggests a natural protection of fatty acids against the biohydrogenation process [58]. Soybean oil has no protection against the enzymatic action of biohydrogenation; consequently, the concentration of C18:2 c9c12 in the LL muscle of lambs fed this diet was lower.

The level of dissociation of calcium salts of fatty acids is higher as the concentration of unsaturated fatty acids increases [59], which explains the lower concentration of C18:2 c9c12 in the LL muscle of lambs fed the CSFA diet. 
The highest concentrations of C18:2 c9t11 were observed in the LL muscle of lambs fed the CSFA, SO, and CG diets. This result indicates that lipid biohydrogenation occurred in these diets. According to Fruet et al. [60], the principal conjugated linoleic acid (CLA) generated in the biohydrogenation process is C18: 2 c9t11 (58.9\%).

The higher concentration of C18:1 t11 observed in the LL muscle of lambs fed the CSFA diet suggest an accumulation of this fatty acid. The increase of C18:1 111 inhibits the final step of biohydrogenation [11]. In this way, this diet has a higher amount of C18:1 t11 and a lower concentration of C18:0, which indicates incomplete biohydrogenation. On the other hand, the higher concentration of C18:0 found in the LL muscle of lambs fed the CG diet suggests complete biohydrogenation of the MUFA and PUFA of this diet.

The high concentrations of C18:3 n-3 and C18:2 n-6 in the LL muscle of lambs fed the WSB diet suggest a lower biohydrogenation of this diet, which explains the higher total concentration of SFA. Fatty acids were protected by cotyledons and other grain seed structures [9], avoiding ruminal bacteria activity and reaching the duodenum in almost the same proportion in which it was supplied [55].

The n-6 (20:4 n-6) and n-3 (C20:5 n-3, C22:5 n-3, and C22:6 n-3) fatty acids found in the LL muscle may come from diet or elongation of the 18:2 n-6 and C18:3 n-3 fatty acids [61]. It should be noted that the inclusion of different fat sources in the diet of lambs, regardless of the degree of ruminal biohydrogenation, increased the PUFA profile in meat [62].

The LL muscle of lambs fed the WSB diet showed higher concentrations of n-6 and n-3 fatty acids, related to the degree of protection of long-chain fatty acids [55] with this diet. This result suggests that whole soybean promoted a higher protection of fatty acids from biohydrogenation, resulting in a higher concentration of PUFA in meat. On the other hand, the PUFA synthesis in these animals is lower due to the lower activities of elongase and desaturase $\left(\Delta^{5}\right.$ and $\left.\Delta^{6}\right)$ enzymes [63].

The SO and CG diets promoted higher concentrations of n- 6 fatty acids and low n-3 fatty acids, indicating greater biohydrogenation of n-3 fatty acids, confirmed by high levels of C18:2 c9t11. The PUFA concentrations are the result of the elongation of fatty acids due to the high elongase activity with these diets.

Stearic acid (C18:0) can be converted to oleic acid (C18:1 $c 9)$ through the enzymatic activity of $\Delta^{9}$ desaturase, through a dehydrogenation reaction, and through the addition of a stereospecific double bond within the chain [63]. The $\Delta^{9} \mathrm{C} 18$ desaturase activity observed in the meat of lambs fed the NAF diet explains the higher concentration of $c 18: 1 c 9$ in the LL muscle of these animals.

The $n-6 / n-3$ ratio is related to the increase in the levels of cholesterol in the blood. In this way, the recommended value for the prevention of cardiovascular diseases should be less than 4 [64]. All treatments showed values within the recommended range. However, the highest value obtained with the CG diet was influenced by the concentrations of n-3 fatty acids.

$\mathrm{AI}$ and TI show the trend in the formation of fatty plaques in the arteries that promote cardiovascular diseases $[54,64]$. The recommended values for AI and TI should be less than 1.0 and 0.5 , respectively [65]. Since AI and TI are functions of the sum of the fatty acids UFA, MUFA, n-6, and n-3, the high values of these free acids influenced the higher values of AI and TI in the LL muscle of lambs fed the WSB diet.

The AI in the LL muscle of the lambs was less than 1.0, and the TI was higher than 0.5. However, the AI and TI values were less than 1.0 and 2.0, respectively. The values observed in the current study are similar to those reported by Bhatt et al. [54] in lambs fed with calcium salts of fatty acids and flaxseed.

The h:H rate below 2.0 is ideal for positively modulating the cholesterol transport mechanism by lipoproteins and the prevention of cardiovascular diseases [64]. The C14:0 and C16:0 values were similar between diets, with the highest concentrations observed in lambs fed the NAF, SO, and CG diets due to the concentrations of the C18:1 $c 9, n-6$, and n-3 fatty acids. 


\section{Conclusions}

The inclusion of $3.5 \%$ of calcium salts of fatty acids as a source of protected fat in the total diet of feedlot lambs results in higher slaughter weight, carcass weight and yield, conformation, finishing, compactness index, and loin eye area of the carcass.

Calcium salts of fatty acids in diets also improve the profile of fatty acids in meat, especially those that are bioactive and important for human health, such as intermediate fatty acids from biohydrogenation and PUFA; in addition, they reduce the SFA content.

Author Contributions: conceptualization, G.G.P.d.C., J.E.d.F.J., S.A.S., and D.S.P.; methodology, G.G.P.d.C., J.E.d.F.J., L.C.L., M.S.L.T., H.D.R.A., and D.S.P.; validation, G.G.P.d.C., D.S.P., and S.A.S.; formal analysis, H.D.R.A., L.G.A.C., W.P.S., and V.G.O.L.; investigation, H.D.R.A., W.P.S., and V.G.O.L.; resources, G.G.P.d.C. and J.A.G.A.; data curation, G.G.P.d.C., D.S.P., S.A.S., and C.S.R.; writing-original draft preparation, H.D.R.A., G.G.P.d.C., and L.G.A.C.; writing-review and editing, G.G.P.d.C., D.S.P., S.A.S., C.S.R., L.C.L., and H.D.R.A.; visualization, G.G.P.d.C., M.S.L.T., D.S.P., and S.A.S.; supervision, G.G.P.d.C., D.S.P., S.A.S., and C.S.R.; project administration, G.G.P.d.C. and J.A.G.A.; funding acquisition, G.G.P.d.C. and J.A.G.A. All authors have read and agreed to the published version of the manuscript.

Funding: This research received no external funding. This research was funded by the Bahia State Research Foundation (FAPESB—grant number: 8390/2014).

Institutional Review Board Statement: This study was conducted in strict accordance with the recommendations presented in the Guide of the National Council for Animal Experimentation Control (CONCEA). The protocol was approved by the Ethics Committee on the Animal Use of the School of Veterinary Medicine and Animal Science at the Federal University of Bahia (Permit number: 69/2018).

Informed Consent Statement: Not applicable.

Data Availability Statement: No new data were created or analyzed in this study. Data sharing is not applicable to this article.

Acknowledgments: The authors are thankful to the Coordenação de Aperfeiçoamento de Pessoal de Nivel Superior (CAPES) and to the Bahia State Research Foundation (FAPESB) for the fellowship grants.

Conflicts of Interest: The authors declare no conflict of interest. The funders had no role in the design of the study; in the collection, analyses, or interpretation of data; in the writing of the manuscript; or in the decision to publish the results.

\section{References}

1. De Souza, J.; Batistel, F.; Santos, F.A.P. Effect of sources of calcium salts of fatty acids on production, nutrient digestibility, energy balance, and carryover effects of early lactation grazing dairy cows. J. Dairy Sci. 2017, 100, 1072-1085. [CrossRef] [PubMed]

2. Zhao, T.; Ma, Y.; Qu, Y.; Luo, H.; Liu, K.; Zuo, Z.; Lu, X. Effect of dietary oil sources on fatty acid composition of ruminal digesta and populations of specific bacteria involved in hydrogenation of 18-carbon unsaturated fatty acid in finishing lambs. Small Rumin. Res. 2016, 144, 126-134. [CrossRef]

3. NRC - National Research Council. Nutrient Requirements of Dairy Cattle, 7th ed.; National Academic Press: Washington, DC, USA, 2001.

4. Messana, J.D.; Berchielli, T.T.; Arcuri, P.B.; Reis, R.A.; Canesin, R.C.; Ribeiro, A.F.; Fiorentini, G.; Fernandes, J.J.D.R. Rumen fermentation and rumen microbes in Nellore steers receiving diets with different lipid contents. Rev. Bras. Zootec. 2013, 42, 204-212. [CrossRef]

5. Pitta, D.; Indugu, N.; Vecchiarelli, B.; Rico, D.; Harvatine, K. Alterations in ruminal bacterial populations at induction and recovery from diet-induced milk fat depression in dairy cows. J. Dairy Sci. 2018, 101, 295-309. [CrossRef]

6. Conte, G.; Serra, A.; Mele, M. Dairy Cow Breeding and Feeding on the Milk Fatty Acid Pattern. In Nutrients in Dairy and their Implications on Health and Disease; Elsevier: Amsterdam, The Netherlands, 2017; pp. 19-41.

7. Alvarado-Gilis, C.A.; Aperce, C.C.; Miller, K.A.; Van Bibber-Krueger, C.L.; Klamfoth, D.; Drouillard, J.S. Protection of polyunsaturated fatty acids against ruminal biohydrogenation: Pilot experiments for three approaches1. J. Anim. Sci. 2015, 93, 3101-3109. [CrossRef]

8. Palmquist, D.L.; Jenkins, T. A 100-Year Review: Fat feeding of dairy cows. J. Dairy Sci. 2017, 100, 10061-10077. [CrossRef] 
9. $\quad$ Freitas, J.; Takiya, C.; Del Valle, T.; Barletta, R.; Venturelli, B.; Vendramini, T.; Mingoti, R.; Calomeni, G.; Gardinal, R.; Gandra, J.; et al. Ruminal biohydrogenation and abomasal flow of fatty acids in lactating cows fed diets supplemented with soybean oil, whole soybeans, or calcium salts of fatty acids. J. Dairy Sci. 2018, 101, 7881-7891. [CrossRef]

10. Gandra, J.R.; Takiya, C.S.; De Oliveira, E.R.; De Paiva, P.G.; de Tonissi e Buschinelli de Goes, R.H.; Gandra Érika, R.D.S.; Araki, H.M.C. Nutrient digestion, microbial protein synthesis, and blood metabolites of Jersey heifers fed chitosan and whole raw soybeans. Rev. Bras. Zootec. 2016, 45, 130-137. [CrossRef]

11. Brandao, V.; Dai, X.; Paula, E.; Silva, L.; Marcondes, M.; Shenkoru, T.; Poulson, S.; Faciola, A. Effect of replacing calcium salts of palm oil with camelina seed at 2 dietary ether extract levels on digestion, ruminal fermentation, and nutrient flow in a dual-flow continuous culture system. J. Dairy Sci. 2018, 101, 5046-5059. [CrossRef]

12. NRC -National Research Council. Nutrient Requirements of Small Ruminants: Sheep, Goats, Cervids, and New World Camelids; National Academic Press: Washington, DC, USA, 2007.

13. AOAC. Official Methods of Analysis of the Association of Official Analytical Chemists, 18th ed.; Association of Official Analytical Chemists Inc.: Gaithersburg, MD, USA, 2005.

14. Van Soest, P.V.; Robertson, J.B.; Lewis, B.A. Methods for Dietary Fiber, Neutral Detergent Fiber, and Nonstarch Polysaccharides in Relation to Animal Nutrition. J. Dairy Sci. 1991, 74, 3583-3597. [CrossRef]

15. AOAC. Official Methods of Analysis of the Association of Official Analytical Chemists, 17th ed.; Association of Official Analytical Chemists Inc.: Washington, DC, USA, 2002.

16. Hall, M.B. Calculation of Non-Structural Carbohydrate Content of Feeds that Contain Non-Protein Nitrogen. University of Florida, Gainesville, FL, USA. Bulletin 2000, 339, 25.

17. Bürger, P.J.; Pereira, J.C.; De Queiroz, A.C.; Da Silva, J.F.C.; Filho, S.D.C.V.; Cecon, P.R.; Casali, A.D.P. Comportamento ingestivo em bezerros holandeses alimentados com dietas contendo diferentes níveis de concentrado. Rev. Bras. Zootec. 2000, 29, $236-242$. [CrossRef]

18. De Carvalho, G.G.; Rebouças, R.; Campos, F.; Santos, E.; Araújo, G.; Gois, G.; De Oliveira, J.; Oliveira, R.; Rufino, L.D.A.; Azevedo, J.; et al. Intake, digestibility, performance, and feeding behavior of lambs fed diets containing silages of different tropical forage species. Anim. Feed. Sci. Technol. 2017, 228, 140-148. [CrossRef]

19. Cézar, M.F.; Sousa, W.H. Sheep and Goat Carcasses: Production, Evaluation and Classification; Uberaba, M.G., Ed.; Agropecuária Tropical: Goiânia, Brazil, 2007.

20. Miltenburg, G.A.J.; Wensing, T.; Smulders, F.J.M.; Breukink, H.J. Relationship between blood hemoglobin, plasma and tissue iron, muscle heme pigment, and carcass color of veal1. J. Anim. Sci. 1992, 70, 2766-2772. [CrossRef] [PubMed]

21. AMSA-American Meat Science Association. Research Guidelines for Cookery, Sensory Evaluation, and Instrumental Tenderness Measurements of Meat, 2nd ed.; American Meat Science Association: Champaign, IL, USA, 2015.

22. Shackelford, S.D.; Wheeler, T.L.; Koohmaraie, M. Evaluation of slice shear force as an objective method of assessing beef longissimus tenderness. J. Anim. Sci. 1999, 77, 2693-2699. [CrossRef] [PubMed]

23. O'Fallon, J.V.; Busboom, J.R.; Nelson, M.L.; Gaskins, C.T. A direct method for fatty acid methyl ester synthesis: Application to wet meat tissues, oils, and feedstuffs. J. Anim. Sci. 2007, 85, 1511-1521. [CrossRef] [PubMed]

24. Kramer, J.K.G.; Fellner, V.; Dugan, M.E.R.; Sauer, F.D.; Mossoba, M.M.; Yurawecz, M.P. Evaluating acid and base catalysts in the methylation of milk and rumen fatty acids with special emphasis on conjugated dienes and total trans fatty acids. Lipids 1997, 32, 1219-1228. [CrossRef] [PubMed]

25. Ulbricht, T.L.V.; Southgate, D.A.T. Coronary heart disease: Seven dietary factors. Lancet 1991, 338, 985-992. [CrossRef]

26. Santossilva, J.; Bessa, R. Effect of genotype, feeding system and slaughter weight on the quality of light lambs. Livest. Prod. Sci. 2002, 77, 187-194. [CrossRef]

27. Rhee, K.S. Fatty acids in meats and meat products. In Fatty Acids in Foods and Their Health Implications; Chow, C.K., Ed.; Marcel Dekker: New York, NY, USA, 1992; pp. 65-93.

28. Malau-Aduli, A.E.O.; Siebert, B.D.; Bottema, C.D.K.; Pitchford, W.S. A comparison of the fatty acid composition of triacylglycerols in adipose tissue from Limousin and Jersey cattle. Aust. J. Agric. Res. 1997, 48, 715. [CrossRef]

29. Kazala, E.C.; Lozeman, F.J.; Mir, P.; Laroche, A.; Bailey, D.R.C.; Weselake, R.J. Relationship of fatty acid composition to intramuscular fat content in beef from crossbred Wagyu cattle. J. Anim. Sci. 1999, 77, 1717-1725. [CrossRef] [PubMed]

30. Urbano, S.A.; Ferreira, M.d.A.; Bispo, S.V.; Silva, E.C.d.; Suassuna, J.M.A.; Oliveira, J.P.F.d. Corn germ meal in replacement of corn in Santa Ines sheep diet: Carcass characteristics and tissue composition. Acta Vet. Bras. 2016, 10, 165-171. [CrossRef]

31. Millen, D.; Arrigoni, M.B.; Pacheco, R.D.L. Rumenology; Springer Nature: Berlin/Heidelberg, Germany, 2016 ; pp. 63-102.

32. Costa, R.G.; Ribeiro, N.; Nobre, P.T.; Carvalho, F.; Medeiros, A.N.; Martins, F.E. Ingestive behavior and efficacy of male sheep housed in different stocking densities. Rev. Bras. Zootec. 2019, 48, 20180219. [CrossRef]

33. Dos Santos, F.M.; De Araújo, G.G.L.; De Souza, L.L.; Yamamoto, S.M.; Queiroz, M.A.Á.; Lanna, D.P.D.; De Moraes, S.A. Impact of water restriction periods on carcass traits and meat quality of feedlot lambs in the Brazilian semi-arid region. Meat Sci. 2019, 156, 196-204. [CrossRef]

34. Souza, J.d.S.; Difante, G.d.S.; Neto, J.V.E.; Lana, Ângela, M.Q.; Roberto, F.F.d.S.; Ribeiro, P.H.C. Biometric measurements of Santa Inês meat sheep reared on Brachiaria brizantha pastures in Northeast Brazil. PLoS ONE 2019, 14, e0219343. [CrossRef] 
35. Fernandes, A.R.M.; Orrico, M.A.P.; Orrico, A.C.A.; Júnior, F.V.; Oliveira, A.B.D.M. Desempenho e características qualitativas da carcaça e da carne de cordeiros terminados em confinamento alimentados com dietas contendo soja grão ou gordura protegida. Rev. Bras. Zootec. 2011, 40, 1822-1829. [CrossRef]

36. Sklan, D.; Nagar, L.; Arieli, A. Effect of feeding different levels of fatty acids or calcium soaps of fatty acids on digestion and metabolizable energy in sheep. Anim. Sci. 1990, 50, 93-98. [CrossRef]

37. Bhatt, R.; Sahoo, A.; Gadekar, Y. Production performance of lambs on milk replacer during pre-weaning followed by post-weaning linseed and calcium soap supplementation. Anim. Feed. Sci. Technol. 2018, 240, 145-156. [CrossRef]

38. Filho, J.G.L.R.; Pereira, E.; Selaive-Villarroel, A.; Pimentel, P.G.; Medeiros, A.N.; Fontenele, R.M.; Maia, I.S.G. Composição corporal e exigências líquidas proteicas de ovinos Santa Inês em crescimento. Rev. Bras. Zootec. 2011, 40, 1339-1346. [CrossRef]

39. Fiorentini, G.; Carvalho, I.P.C.; Messana, J.D.; Castagnino, P.S.; Berndt, A.; Canesin, R.C.; Frighetto, R.T.S.; Berchielli, T.T. Effect of lipid sources with different fatty acid profiles on the intake, performance, and methane emissions of feedlot Nellore steers1. J. Anim. Sci. 2014, 92, 1613-1620. [CrossRef]

40. Urbano, S.A.; Ferreira, M.D.A.; Madruga, M.S.; De Azevedo, P.S.; Bispo, S.V.; Da Silva, E.C. Corn germ meal as substitute for corn in the diet of confined Santa Inês sheep: Chemical and lipid meat composition. Ciência Agrotecnologia 2014, 38, 581-588. [CrossRef]

41. Junior, A.C.H.; Ezequiel, J.M.B.; Fávaro, V.R.; Perez, H.L.; Almeida, M.T.C.; Paschoaloto, J.R.; D'áurea, A.P.; Carvalho, V.B.; Nocera, B.F. Fontes de lipídios e classe sexual no confinamento de ovinos. Semina Ciências Agrárias 2015, 36, 2165-2174. [CrossRef]

42. Cleef, F.D.O.S.V.; Ezequiel, J.M.B.; D’Aurea, A.P.; Almeida, M.T.C.; Perez, H.L.; Van Cleef, E.H.C.B. Feeding behavior, nutrient digestibility, feedlot performance, carcass traits, and meat characteristics of crossbred lambs fed high levels of yellow grease or soybean oil. Small Rumin. Res. 2016, 137, 151-156. [CrossRef]

43. Chulayo, A.Y.; Muchenje, V. The Effects of Pre-slaughter Stress and Season on the Activity of Plasma Creatine Kinase and Mutton Quality from Different Sheep Breeds Slaughtered at a Smallholder Abattoir. Asian-Australas. J. Anim. Sci. 2013, 26, 1762-1772. [CrossRef] [PubMed]

44. Oliveira, A.F.; Rodrigues, S.; Leite, A.; Paulos, K.; Pereira, E.; Teixeira, A. Short Communication: Quality of ewe and goat meat cured productmantas. An approach to provide value added to culled animals. Can. J. Anim. Sci. 2014, 94, 459-462. [CrossRef]

45. Carneiro, M.M.Y.; de Tonissi e Buschinelli de Goes, R.H.; Da Silva, L.H.X.; Fernandes, A.R.M.; De Oliveira, R.T.; Cardoso, C.A.L.; Hirata, A.S.O. Quality traits and lipid composition of meat from crossbreed Santa Ines ewes fed diets including crushed crambe. Rev. Bras. Zootec. 2016, 45, 319-327. [CrossRef]

46. Shange, N.; Makasi, T.N.; Gouws, P.A.; Hoffman, L.C. The influence of normal and high ultimate muscle pH on the microbi-ology and colour stability of previously frozen black wildebeest (Connochaetes gnou) meat. Meat Sci. 2018, 135, 14-19. [CrossRef]

47. Bonagurio, S.; Pérez, J.R.O.; Garcia, I.F.F.; Bressan, M.C.; Lemos, A.L.S.C. Quality of meat production of purebred Santa Inês and crossbred Texel x Santa Inês lambs at different slaughter weights. Rev. Bras. Zootec. 2003, 32, 1981-1991. [CrossRef]

48. Sobrinho, A.G.D.S.; Purchas, R.W.; Kadim, I.T.; Yamamoto, S.M. Características de qualidade da carne de ovinos de diferentes genótipos e idades ao abate. Rev. Bras. Zootec. 2005, 34, 1070-1078. [CrossRef]

49. Sañudo, C.; Enser, M.; Campo, M.; Nute, G.; Marı, G.; Sierra, I.; Wood, J. Fatty acid composition and sensory characteristics of lamb carcasses from Britain and Spain. Meat Sci. 2000, 54, 339-346. [CrossRef]

50. Hedrick, H.B.; Aberle, E.D.; Forrest, J.C.; Judge, M.D.; Mer-kel, R.A. Principles of Meat Science; Kendall-Hunt Publishing Company: Dubuque, IA, USA, 1994.

51. Hopkins, D.; Allingham, P.; Colgrave, M.L.; Van De Ven, R. Interrelationship between measures of collagen, compression, shear force and tenderness. Meat Sci. 2013, 95, 219-223. [CrossRef] [PubMed]

52. Pinheiro, R.; Jorge, A.; Souza, H.; Boiago, M. Coloração da gordura e qualidade da carne de ovelhas de descarte abatidas em distintos estágios fisiológicos. Arq. Bras. Med. Veterinária Zootec. 2010, 62, 468-474. [CrossRef]

53. Souza, D.; Selaive-Villarroel, A.; Pereira, E.; Silva, E.; Oliveira, R. Effect of the Dorper breed on the performance, carcass and meat traits of lambs bred from Santa Inês sheep. Small Rumin. Res. 2016, 145, 76-80. [CrossRef]

54. Bhatt, R.S.; Soni, L.K.; Sahoo, A.; Gadekar, Y.; Sarkar, S. Dietary supplementation of extruded linseed and calcium soap for augmenting meat attributes and fatty acid profile of longissimus thoracis muscle and adipose tissue in finisher Malpura lambs. Small Rumin. Res. 2020, 184, 106062. [CrossRef]

55. Vahmani, P.; Ponnampalam, E.N.; Kraft, J.; Mapiye, C.; Bermingham, E.; Watkins, P.; Proctor, S.D.; Dugan, M.E.R. Bioactivity and health effects of ruminant meat lipids. Invited Review. Meat Sci. 2020, 165, 108114. [CrossRef]

56. Børsting, C.; Brask, M.; Hellwing, A.L.F.; Weisbjerg, M.R.; Lund, P. Enteric methane emission and digestion in dairy cows fed wheat or molasses. J. Dairy Sci. 2020, 103, 1448-1462. [CrossRef]

57. Fievez, V.; Colman, E.; Montoya, J.C.; Stefanov, I.; Vlaeminck, B. Milk odd- and branched-chain fatty acids as biomarkers of rumen function-An update. Anim. Feed. Sci. Technol. 2012, 172, 51-65. [CrossRef]

58. Doreau, M.; Meynadier, A.; Fievez, V.; Ferlay, A. Ruminal metabolism of fatty acids: Modulation of polyunsaturated, conju-gated, and trans fatty acids in meat and milk. In Handbook of Lipids in Human Function; Watson, R.R., Meester, F., Eds.; AOCS Press: San Diego, CA, USA, 2016; pp. 521-542.

59. Naik, P.K. Bypass fat in dairy ration-a review. Anim. Nutr. Feed Technol. 2013, 13, 147-163. 
60. Fruet, A.; Trombetta, F.; Stefanello, F.; Speroni, C.; Donadel, J.; De Souza, A.; Júnior, A.R.; Tonetto, C.; Wagner, R.; De Mello, A.; et al. Effects of feeding legume-grass pasture and different concentrate levels on fatty acid profile, volatile compounds, and off-flavor of the M. longissimus thoracis. Meat Sci. 2018, 140, 112-118. [CrossRef]

61. Patterson, E.; Wall, R.; Fitzgerald, G.F.; Ross, R.P.; Stanton, C. Health Implications of High Dietary Omega-6 Polyunsaturated Fatty Acids. J. Nutr. Metab. 2012, 2012, 1-16. [CrossRef]

62. Miltko, R.; Majewska, M.P.; Bełżecki, G.; Kula, K.; Kowalik, B. Growth performance, carcass and meat quality of lambs supplemented different vegetable oils. Asian-Australasian, J. Anim. Sci. 2019, 32, 767-775. [CrossRef]

63. Zhang, J.Y.; Kothapalli, K.S.; Brenna, J.T. Desaturase and elongase-limiting endogenous long-chain polyunsaturated fatty acid biosynthesis. Curr. Opin. Clin. Nutr. Metab. Care 2016, 19, 103-110. [CrossRef] [PubMed]

64. Parodi, P.W. Dietary guidelines for saturated fatty acids are not supported by the evidence. Int. Dairy J. 2016, 52, 115-123. [CrossRef]

65. Wołoszyn, J.; Haraf, G.; Okruszek, A.; Wereńska, M.; Goluch, Z.; Teleszko, M. Fatty acid profiles and health lipid indices in the breast muscles of local Polish goose varieties. Poult. Sci. 2020, 99, 1216-1224. [CrossRef] [PubMed] 